\title{
Bulgarian, Russian and Ukrainian Terminology in Cinematography: Origin and Conceptual Structure of Terminological Units
}

\author{
Radostina Stoyanova ${ }^{1,2, *}$ \\ ${ }^{1}$ Institute for Bulgarian Language "Prof. L. Andreychin", Bulgarian Academy of Sciences, Sofia, Bulgaria \\ ${ }^{2}$ University of Economics - Varna, Varna, Bulgaria \\ *Corresponding author. Email: r.stoyanova@ibl.bas.bg
}

\begin{abstract}
This article presents observations on the modern Bulgarian, Russian and Ukrainian film terminology as an art form. Special attention is paid to the phenomena of migration and borrowing of terms as methods of the discipline-specific vocabulary replenishment. The structural design of terminological units related to cinematography $e$ is also considered.
\end{abstract}

Keywords: cinematography, terms, terminology, Bulgarian language, Russian language, Ukrainian language

\section{INTRODUCTION}

Cinematography is a relatively new art form.

Cinema as a form of creative art is a synthesis of the literature, visual arts, theater, and music.

Cinematography terms combine theater, musical, artistic, aesthetic, technical concepts, as well as concepts and terms from other scientific disciplines, which is evidence of the versatility of its specific vocabulary.

The relevance of this research is due to the lack of studies and description of the modern cinematography terminology in Bulgarian, Russian and Ukrainian languages.

The purpose of the article is to analyze the modern film terminology in three Slavic languages - Bulgarian, Russian, and Ukrainian from the point of view of the origin and derivational modeling.

\section{RESEARCH SOURCES}

The sources used for the research were: cinematography dictionaries and studies materials, Internet resources related to cinematography [1], [2], [3], [4], [5], [6], etc.

\section{THE TREND TOWARDS MIGRATION OF TERMS IN CINEMATOGRAPHY}

Globalization and digitalization of all spheres of social life, and art in particular, have an impact on the trend towards transterminologization and internationalization of the terminology of art, whose boundaries are open to new terms.

The increasing trend towards interdisciplinarity of scientific research opens the boundaries of art history science and its terminology. The result of this process is the migration of terms from other disciplines.

Film /cinematography terminology is based and functions across different professional fields: 3D technology, computer graphics, covers areas such as lighting, make-up, cinematographic management, filming equipment, acting, etc. [7: 99]. According to V.A. Batig, these are separate independent terminolog ${ }_{H}$ systems that can be considered as subdomains of the cinematography terminolog ${ }_{H}$ system, or, on the contrary, the film industry should be divided into separate sub-sectors with separate glossaries. [7: 99].

Migration of terms towards cinematography terminology occurs on the basis of different initial scientific domains - architecture (bulg. декор - rus. декор - ukr. декор /en. decor/; bulg. павилион - rus. павильон - ukr. павільйон /en. pavilion/), literature (bulg. комикси - rus. комиксы - ukr. комікси /en. comics/; bulg. нежен реализъм - rus. нежный реализм - ukr. ніжний реалізм /en. gentle realism/), theatre (bulg. кинодрама - rus. кинодрама - ukr. кінодрама /en. drama movie/; bulg. камершпиле - rus. каммершпиле - ukr. камершпіле /en. Kammerspielfilm/), aesthetics (bulg. кич - pус. китч /кич/ - укр. кітч /кіч/ /en. kitsch/), еconomics (bulg. маркетинг - rus. маркетинг - ukr. маркетинг /en. marketing.; bulg. киноикономика - rus. киноэкономика - ukr. кіноекономіка /en economics of cinema/; bulg. киноиндустрия - rus. киноиндустрия - ukr. кіноіндустрія /en. film 
industry.), etc. Thus, the cinematography terminology is an extensive terminology system open to the entry of new terms.

On the other hand, the film industry, as V. A. Batig emphasizes, contributes to the development of various technologies specifically in film criticism, and cinema art in general. The arising of new technologies, creative ideas, and concepts is an indicator that the film industry replenishes the terminology resources of related domains [7: 99].

Both terms of local origin wn the Bulgarian, Russian and Ukrainian film terminology systems are used (rus. агитки [agitky] (en. agitky) - early genre of Soviet cinema; short films in the style of posters and news sheets "[1: 11]; rus. эффект Кулешова - bulg. ефект на Кулешов - ukr. "ефект Кулешова" /en. Kuleshov effect/), and borrowed from other languages in different periods (bulg. кадър - rus. кадр (кинокадр) - ukr. кінокадр > fr. cadre (en. frame) ,a still image on a film strip recording one phase of motion of a moving object or its static position" [1: 273]; bulg. трильр - rus. триллер - ukr. трилер > en. thriller , a genre of an adventure film, where the storyline is built on the audience's active empathy for the action taking place on the screen, provoking emotional escalation, fear, excitement, an expectation of a surprising ending "[1:586]).

\section{BORROWING AS A METHOD OF FILM TERMINOLOGY REPLENISHMENT}

Linguistic borrowing being a universal method of enriching the vocabulary helped to create cinematography terminology resources in Bulgarian, Russian, and Ukrainian languages.

In terminology science, borrowing is considered as one of the ways of creating terms, when lexical units are transferred from one natural language or language for special purposes to another natural language or language for special purposes "[8: 141].

Borrowed terms, mainly of English-language origin, are encountered quite often in Bulgarian, Russian, and Ukrainian cinematography terminology systems. These terms reflect in linguistic form the main stages, directions, and specifics of the creation of a conceptual system of this domain. We perceive many basic film terms, borrowed by Bulgarian, Russian, and Ukrainian from different donor languages and adopted in the vocabulary of the three languages, as having lost their foreign origin. For example:

bulg. екран - rus. экран - ukr. екран < fr. écran; (eng screen);

bulg. камера - rus. камера - ukr. камера $<$ lat. camera;(en. camera); bulg. кино - rus. кино - ukr. кіно $<$ anc.greek

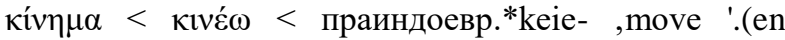
cinema, movie).

\section{A. Greko-Latin borrowings in cinematography terminology}

Terms representing Greek-Latin borrowings are lexemes made up of Greek-Latin morphemes that have great potential to denote scientific concepts of an international nature. Terms containing Greek-Latin morphemes are the basic source for replenishment of certain terminology systems in various literary languages, and in particular in Bulgarian, Russian, and Ukrainian. For example:

bulg. амфитеатьр - rus. амфитеатр - укр. амфітеатр > греч. $\alpha \mu \varphi \imath \theta \varepsilon \dot{\varepsilon} \alpha \tau \rho \mathrm{v} /$ amfiqeatron/(en. amphitheater) ,1. architectural structure in ancient Rome used for public events (gladiatorial combats, animal slayings- bestiary, naval battles - navmachia), normally large, circular or oval theatre, with an open-air arena in the center and raised seating area around it $[. .$. 2. Spectators seats in enclosed spaces, located in arched open tiers (in theaters, cinemas, auditoriums) or around an arena (in a circus)." [1:32];

bulg. мултиплекс - rus. мультиплекс - ukr. мультиплекс /малтіплекс/ (en. multiplex) ,movie theater complex with multiple screens with computer and soundeffects." [1: 409];

bulg. мултипликационно (анимационно) кино rus. мультипликационное (анимационное) кино ukr. мультиплікаційне (анімаційне) кіно /анімація/ > лат. Multiplicatio (en. animated cinematography cartoons) - , art based on the illusion of movement (animation) of drawn, various volumetric (doll, plasticine, bas-relief, etc.), pictorial images recorded on film by the method of stop-frame process". [1: 410], comp.:

bulg. анимаиионно кино - rus. анимационное кино (анимация), en. animation, fr. animation, it. animazione > lat. animatus. comp.:

ukr. анімаційне кіно /анімаџія/ (мультиплікаційне кіно) (en. animation films), animation - bestowing of life, this is where the medical term "reanimation" comes from. In Ukrainian animation is also called the art of multiplication (literally - reproduction))". [3: 7];

bkg. кинохроника - rus. кинохроника -ukr.

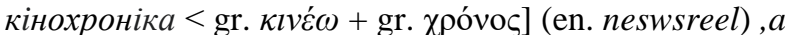
type of cinematic art based on shooting of current events" [2];

bulg. неореализъм - rus. неореализм - ukr. неореалізм < gr. Neos + lat. Reales (en. neo-realism), the meaning of the term is "new realism", that 
characterizes the films produced in Italy in 1945-1949." [3: 88].

Some terms with Greco-Latin morphemes were borrowed to Bulgarian, Russian, and Ukrainian through an intermediary language. For example, in Russian, a camera for moving pictures shooting, called by the Lumiere brothers 'cinématographe', was borrowed both through German language. (rus. кинематограф), and through French (rus. синематограф). Later, the version кинематограф became dominant in the Russian language. The German and Bulgarian languages also adopted the German variant bulg. кинематограф - ukr. кінематограф (less often - ukr. сінематограф, ukr. сінематографія ). Comp.:

bulg. кинематограф - rus. кинематограф - ukr. кінематограф < ger. Kinematograph and < fr. cinématographe $[<$ greek. $\kappa i v \varepsilon \mu \alpha$, movement' and

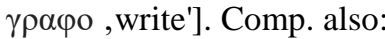

bulg. декор - рус. декор - borrowed from French decor < лат. decoro (eng. decor);

bulg. павилион - rus. павильон - ukr. павільйон borrowed from French pavillion < lat. papilio (eng. pavilion);

bulg. киноалюзия /алюзия в киното/ - rus. киноаллюзия /аллюзия в кинематографе/ - ukr. алюзія в кіно /алюзивне кіно/- borrowed from English allusion $>$ lat. allusion;

bulg. интерактивно кино - rus. интерактивное кино - ukr. інтерактивне кіно borrowed from English interactive cinema $<$ lat. inter , between'+ lat. actio ,action'.

The above terms are international and constitute the basic terminology for the naming of cinematic concepts. They are well adapted to the word-forming system of the three languages. Some new terms also appear on their basis.

bulg. кино $\rightarrow$ киноактьор, киноархив, кинодеец, кинозала, киновлак, кинознание, кинодраматургия, киноизкуство, киноиндустрия, кинолента, кинолетопись, киноклуб, кинокомедия, кинокритика, киномрежа, кинообразование, кинооператор, киноплощадка, кино промишленост, кинопропаганда, кинорепортаж, киносалон, киностудия, кинотеатър, кинотеория, кинотворец, кинохроника, кинофабрика, кинофилм, etc.;

rus. кино $\rightarrow$ киноактёр, киноархив, киноведение, кинодраматургия, кинодеятель, киножурнал, кинозал, киноиндустрия, киноискусство, кинокартина, киноклубы, кинокритика, кинолениниана, кинолента, кинолетопись, кинолитература, кинокомедия, киноплощадка, кинообразование, кинооператор, кинопаремии, кинопоезд, кинопоказ, кинопрокат, кинопромышленность, кинопропаганда, кинорепортаж, кинореформист, киносалон, киносеанс, киносеть, киноскрипт, кинословари, кинотеатр, кинотеория, кинохроника, кинофильм, киностроительство, киностудия, кинотворец, кинотехника, кинофабрика, кинофикация, киноэкспрессионизм, киноэнциклопедия, etc. Comp.: rus. rus. КИНОКИ (en. КІNOКІ) "a group of young Soviet documentarians (see Documentary Film) of the 1920s, who considered their goal to capture reality with photographic accuracy to the point of denying fiction films. They stated that the "Movie Eye" (hence the name of the group) more accurately reflects reality than the human eye. The leader and the ideologist of the group and its main ideologue was director Dziga Vertov." [1: 291]. Comp. ukr. КІНОКИ "a group of young Russian documentarians, formed in 1919 and led by Dzyga Vertov." [3: 79]; ukr. кінозірка (en. movie star). "a concet originated in American cinema in the 1910s and then spread in European cinema [3: 22];

ukr. кіно $\rightarrow$ кіноактер, кінозал, кінозірка, кінознавство, кінопропаганда, кінодекламація, кіножанр, кіноекспресіонізм, кінокадр, кінокамера, кінокоманда, кінопаремії, кіноскрипт, кінодраматургія, кіномистецтво, кінофірма, кінокомпанія, кінопалата, кіновиробництво, кінопересувка, кіноплівка, кінопрокат кінопрокатний, кіноіндустрія, кінолабораторія, кінофестивал, кінофікація, кінофільм, кіноконцерн, кінематографіст, кіномитещь, кінонарис, кінопромисловість, кінопроцес, кінорепортер, кінохроніка и др., etc.

\section{B. Borrowings from English, Italian, German, French in the cinematography terminology}

1) Borrowing from English: In the modern Bulgarian, Russian, and Ukrainian film terminology borrowed term were taken mainly from English (bulg. мокбастьр - rus. мокбастер - urk. мокбастер < en. mockbuster; bulg. блексплойтейшън - rus. блексплойтейшен / блэксплойтэйшен < en blaxploitation, etc.).

V.A. Batig notes that "Since the 1980s, the Russian language has been actively borrowing genre names from English, and since the mid-1990s, these borrowings have lost their systemic character and have become mainly a way of situational categorization of film production." [7: 102-103].

Comp.: bulg. ъндърграунд - rus. андеграунд (андерграунд) $<$ англ. underground) ,artistic trends in Western European and Russian art (in music, literature, cinema, fine arts, etc.), in opposition to official art" [1: 34]; 
bulg. римейк - rus. ремейк / римейк < en. remake , a form of creative recoding and a new interpretation of previously published works (musical, literary, cinematic) "[4: 200], a film repeating the plot of an earlier produced well-known film. The goal is to use a commercially successful plot in combination using the latest technology." [1: 509];

rus. видеомикшер < en. vision mixer ,a device uniting several different video sources to create a composite video. устройство для объединения видеосигналов нескольких телевизионных датчиков с целью формирования комбинированного изображения" [5];

bulg. виставижън - rus. виставижн / виста-вижн $<$ en. VistaVision (Vistavision Motion Picture HighFidelity), is a widescreen cinematographic system using the 35 film with horizontal pulldown and spherical (axially symmetric) lenses"1;

rus. артхаус / арт-хаус - ukr. арт-кіно, арт-хаус > en. art house (art cinema, art movie, art film), Earlier, a theatre, which presented avant-garde or classic films for the prepared audience. Such films were intended for a more experienced audience, and theatres were often located near colleges and universities." [3: 9];

bulg. маркетинг - rus. маркетинг - ukr. маркетинг (en. marketing) ,adaptation of film production to the market basing on the study of consumer demand. Active marketing is a series of activities (including advertising) aimed at increasing demand for a film" [3: 265];

rus. цифровой интермедиэйт (цифровая промежуточная копия ) > eng.digital intermediate, etc..

2) Borrowings from Italian language: bulg. джало филм - rus. джалло, джиалло - ukr. жовтий фільм > it. giallo;

"KIHO

"КОНТЕСТАЦІЇ"

(en.

"CONTESTATION" CINEMA) is a trend in Italian cinema originated in the mid-1960s, when rebellious young people sought to break with their petty-bourgeois existence and go to distant lands - to Africa or India, where it is only possible to find the desired meaning. being. "Contestation" proclaimed a revolutionary protest against society and state." [3: 76].

3) Borrowings from German language: bulg. кич rus. китч (кич) - ukr. кітч (кіч) < ger. Kitsch (en. Kitsch) , a term that first defined a poorly made object for sale, and later became a term of aesthetics. Kitsch is the principle of creation an aesthetic object of" mass

\footnotetext{
1 VistaVision. Wikipedia, the free encyclopedia $<$ https://ru.wikipedia.org/wiki/VistaVision>
}

culture ", which indulges the mass notions of beauty, including cinema." [3: 24];

blg, калигаризъм" - rus. ,калигаризм" - ukr калігаризм < ger. Caligarisme (en. caglgaarism), The term originated after the German expressionist film The Cabinet of Dr. Caligari (1919) and was introduced in France after World War I." Caligarism "was used to describe post-war Europe, in which everything was turned upside down." [3: 74];

bulg. камершпиле - rus. каммершпиле - ukr. камершпіле < ger. kammerspiele (en. kammerspielfim) ,a kind of drama created in German theater, art and cinema in the early 1920 s as a protest against the irrationality of the expressionism." [3: 74];

bulg. нова вещественост - rus. новая вещественность - ukr. нова речевість $<$ ger. Neue Sachlichkeit (en. The New Objectivity) ,a movement in German cinema emerged in the mid-1920s as a reaction against Expressionism." [3: 90]

comp.: rus. культурфильм - ukr. культурфільм < ger. Kulturfilm (en. Kurlturfilm) "a term, little know by a non-specialist related to to archival cinematography. It was borrowed from German (Kulturfilm) in the $1920 \mathrm{~s}$ and referred to films with agitation, moralizing and educational rhetoric, produced in a large amountin the Soviet Union other countries with developed film industry."2;

,Kulturefilms in 1920s films were produced withs an educational purpose, on the one hand, and "to show life" without actors and pavilions" on the other hand. Subsequently, this term was replaced by the concepts of documentary, popular science, educational films." ${ }^{3}$;

rus. „КУЛЬТУРФИЛЬМ, культурфильма [KUL'TURFIL'M, kul'turfil'ma], муж. (en. kulturefilm, masc.), and КУЛЬТУРФИЛЬМА, культурфильмы [KUL'TURFIL'MA, kul'turfil'my] (en. kulturefilma, kulturefilms, fem.) (neol.). Cinematographic educational film of..." (Кинематографический (кинематографическая) фильм (фильма) учебнопросветительного содержания.)

4) Borrowings from French: bulg. амплоа - rus. амплуа - ukr. амплуа < fr. emploi (en. types of roles that an actor usually plays, corresponding to his age, appearance and style of acting; tragedian, comedian, hero-lover, chambermaid, ingénue, travesty, idiot, arguer, etc."[3: 7];

bulg. ракурс - рус. ракурс - укр. ракурс $>$ fr. raccourcir (en. foreshortening), reduction of sizes and forms of real and imaginary objects and figures when

2 What are kulturefilms? About one genre in the Soviet cinema $<$ https://glukk.com/kulturfilm/>

3 Kulturefilm. Through Soviet eyes

$<$ https://old.kinoart.ru/blogs/kulturfilm-videt-po-sovetski $>$ 
they move away from an eye according to laws of linear perspective. The concept of "foreshorten" is applied especially to objects which as a whole or in parts are viewed from unexpected points and sharp angles of view (close, from top to bottom, from bottom to top, etc.) $[\ldots]$ The issue of foreshortening also exists in perspective relief, in illustrations that use strong spatial and scale contrasts, in cinema" [1: 498-499];

rus. камера-перо - ukr. камера стіло $>$ fr. camérastylo, comp. ukr КАМЕРА СТІЛО (eng. camera-pen) ,is a term introduced by a French director Alexandre Astruc in 1948 in one of his program texts, comparing the camera with a pen, which allows you to write with a camera as freely as a writer does with a pen." [3: 74].

\section{THE STRUCTURAL CONCEPT OF CINEMATOGRAPHY TERMS IN BULGARIAN, RUSSIAN AND ENGLISH LANGUAGES}

The structural concept of the film terms in Bulgarian, Russian and Ukrainian will be analyzed based on the number and nature of root morphemes and using of word-forming affixes in naming. [9: 605]

The word-forming structure of film terms in synchrony may be grouped as follows: terms formed by a simple word, terms formed by a derivative word, terms formed by a phrase.

\section{A. Termes formed by a simple word}

The terms formed by a simple word with a nonderivative stem. Such terms are not based on another monosyllabic word: bog. frame - Russian. frame - ukr. frame. кадър - rus. кадр - ukr. кадр (en. frame).

\section{B. Terms formed by a derivative word}

Terms formed by a derivative word, which meaning derived from the meanings of the term components: stems and word-forming affixes.

Affixation, or a process of adding an affix to a root or a stem is one of the most productive ways of word forming in terminology science.

Prefixes and suffixes are service lexical morphemes that do not coincide with the stems of self-contained lexical units in the language (prefixes precede the stem; suffixes follow it) [9: 605].

The terms formed by a derivative word in Bulgarian, Russian, and Ukrainian language corpora are represented by:

1) Terms-nouns: bulg. полиекран - rus. полиэкран (en. multiscreen), two frames with a separate image in the screen perimeter [10]; 1 . A screen on which several images are displayed at the same time. 2. A method of simultaneously displaying several thematically related images [5];

bulg. разкадровка - rus. раскадровка (en. shot breakdown), drawn by hand film shots." [1: 500]; bulg. кинокадър - rus. кинокадр (en. film frame) ,a still image on a film strip recording one phase of the motion of a moving object or its static position." [1:273].

2) Terminology elements-adjectives: bulg. вътрешнокадров монтаж - rus. внутрикадровый монтаж (en. intra-frame editing) -editing by changing of the main characteristics of the frame - the size of the image, the angle, the movements of the camera or the captured objects "[11: 128];

bulg. междукадров монтаж - rus. междукадровый монтаж (en. inter-frame editing), creating of a logical sequence of individual frames" [10: 128];

bulg. полиекранно кино - rus. полиэкранное кино (en. multiscreen films), a type of cinematography that provides simultaneous display of several thematically related images on different parts of one screen or on several adjacent screens (multiscreen); images are projected by several movie projectors using different film copies "[5], ср. также: bulg. полиекранен филм - rus. полиэкранный фильм. (en. multiscreen film)

Various prefixes and semi-prefixes (both international and prefixes of the general literary language) are used in the prefix-suffix way of forming of noun and adjective terms in Bulgarian, Russian and Ukrainian languages. For example:

bulg. анти- [anti-] - rus. анти- [anti-] - ukr. анти[anti-] (en. anti):

bulg. антигерой - rus. антигерой,comp. ukr. антигерой (en. anti-hero);

bulg. интер- [inter-] - rus. интер- [inter-] - ukr. iнтер- [inter-] (en. inter):

bulg. интерактивно кино - rus. интерактивное кино - укр. інтерактивне кіно (en. interactive cinema);

bulg. мулти- [multi-] - rus. мульти- [mul'ti-] - ukr. мульти [multi-] (en. multi-):

bulg. мултиплекс - рус. мультиплекс - ukr. мультиплекс /variant: малтіплекс/ (en. multiplex);

bulg. мултипликационно кино - рус. мультипликационное кино - укр. мультиплікаційне кіно; (еn. animation films)

bulg. пост- [post-] - pyc. пост- [post-] - укр. пост[post-] (en.post): 
bulg. постмодернистичен филм - rus. постмодернистский фильм - ukr. постмодерністський фільм (en. postmodernist film);

bulg. интер- [inter-] - rus. интер- [inter-] - ukr. інтер- [inter-] (en. inter):

bulg. интерактивно кино - rus. интерактивное кино - ukr. інтерактивне кіно (en. interactive cinema);

rus. Интерфильм, rus. Интерфильмовость, etc. (en. interfilm) de):

bulg. де- [de-] - rus. де- [de-] - ukr. де- [de-] (en.

bulg. дедраматизация - rus. дедраматизация ukr. дедраматизація (en. dedramatization);

rus. контра- [kontra-] - urk. контр- [kontr-] (en. counter):

rus. контрапропагандистские фильмы - ukr. контрпропагандистські (en.counterpropaganda);

bulg. псевдо- [psevdo-] - rus. псевдо- [psevdo-] ukr. псевдо- [psevdo-] (en. pseudo):

bulg. псевдодокументален филм - rus. псевдодокументальный фильм псевдодокументальний фільм (en. mockumentary).

M. Popova emphasizes that in Bulgarian language the attribute 'foreign /international' participates in terminological naming - both for local and directly borrowed from other languages terms, much more often than it happens in the general literary vocabulary." [12: 376].

\section{Terms formed by a complex word}

In the Bulgarian, Russian, and Ukrainian film terminology, a common way of terminological naming is the creation of terms by a complex word.

Complex terms have two or more stems, that coincide with the forms given in dictionaries. The complex terms' characteristic is a large amount of information concentrated in the basic terminological unit. They have a capacious structure both from the point of view of economics and semantics, which favors an optimal naming of a special term.

The terms formed by complex words are created by stem composition. According to M. Popova, in modern Bulgarian terminology stem composition is broadly represented as a morphological technique of terminological naming [12: 378]. We can observe a similar process in the Russian and Ukrainian film terminology.

When such terms are being created, lexical elements can be connected by a connecting morpheme: bulg. филмоскоп - rus. фильмоскоп - ukr. фільмоскоп > eng. film 'фильм' + gr. skopeo ,I look';

bulg. филмостат - rus. фильмостат - ukr. фільмостат < en. film 'фильм' + gr. statos 'standing;

rus. фильмокопия - укр. фільмокопія (eng. film print);

bulg. пълнометражен филм - rus. полнометражный фильм - укр. повнометражний фільм (еn. feature film);

bulg. късометражен филм - rus. короткометражный фильм - укр. короткометражний фільм (en. short film);

bulg. вътрешнокадров монтаж - rus. внутрикадровый монтаж - ukr. внутрішньокадровий монтаж (en. intra-frame editing);

rus. широкоэкранный кинематограф (en. widescreen cinema), etc.

On the base of studied material, we may see compound terms, including two borrowed components connected by a hyphen both in Russian and Ukrainian terminology (rus. арт-хаус; rus. кино-новелла; rus. кино-пьеса; rus. кино-поэма; rus. кино-сеанс; rus. кино-спектакль; rus. кино-фронт; rus. художникгриммёр; rus. фильм-спектакль, ukr. фільм-вистава). Comp. also:

rus. фильм-ревю - ukr. фільм-ревю > fr. revue;

ukr. кенгуру-вестерн > en. kangaroo-western;

ukr. "спагеті-вестерн" > en. spaghetti western;

ukr. "спагеті-хорор" > en. spaghetti horror, etc.

There may be cases of complex terms formation when one of the stems is complete, and the other is incomplete:

rus. докудрама (> документальная драма) ср.: bulg. документална драма - ukr. документальна драма (en. documentary drama);

rus. культурфильм - ukr. культурфільм (en. kulturefilm).

\section{Terms formed by a phrase}

A rather productive way of replenishing of Bulgarian, Russian and Ukrainian film terminological vocabulary is syntagmatic naming, ie. naming by using phrases.

Based on the number of constituent components, phrasal cinematography terms are divided into two- and multicomponent.

1) Two-component terms: Two-component phrasal terms' characteristic is that one part of them is common 
to other terms, and the other part consists of its distinguishing feature in a number of related concepts. Such terminological units consist of a determinant and a term:

bulg. независимо кино - rus. независимое кино, ukr. незалежне кіно (en. independent cinema); compare.: rus. независимый кинематограф - ukr. незалежне кіновиробництво (en. independent film production);

bulg. филмово студио (en. film studio);

rus. кинокопировальные фабрики - ukr. кінокопіювальні фабрики (en.film printing factories);

rus. пропагандистские мультфильмы (en. propaganda cartoons);

rus. монтажный кадр (en. frame for editing);

rus. сценарный кадр (en. frame description);

rus. фронтовая кинохроника (en. frontline newsreel);

rus. коммутационно-распределительное оборудование (en. switching and distribution equipment).

2) Multicomponent terms: Three-component terms are the most common form of multicomponent terms in Bulgarian, Russian, and Ukrainian film terminology.

Three-component terms

bulg. изразителни средства на киноизкуството pус. выразительные средства киноискусства - ukr. виражальні засоби кіномистецтва (en. expressive means of cinema);

bulg. младо немско кино (ново немско кино) rus. молодое немецкое кино (новое немецкое кино) - ukr. молоде німецьке кіно (нове німецьке кіно (en. New German Cinema);

bulg. рекламна кампания на филм - rus. рекламная кампания фильма - ukr. рекламна кампанія фільму (en. film advertising campaign);

rus. передача видео сигнала (en. video signal transmission);

rus. синема нового джало (en. the New giallo cinema);

rus. цифровая промежуточная копия (цифровой интермедиэйт) (en. digital intermediate);

rus. телепиеса на документална основа - pус. телепьеса на документальной основе (TV-play on documentary basis);

ukr. нове гонконгське кіно (en. New Hong Kong Cinema); ukr. образотворче рішення фільму (en. film visual solution);

ukr. Російська "золота серія" (en. Russian Golden Series);

ukr. кіно категорії "A" (en. A-category film);

ukr. кіно категорії "Б" (en. B-category film);

ukr. кіно категорії "3" (en. Z-category film), etc.

Four-component terms

bulg. телевизионна пиеса на документална основа (но: телепиеса на документална основа) (en. TV-play on documentary basis);

rus. глубина резкости изображаемого пространства (en. depth of field in front), etc.

Multicomponent terminological phrases in the film terminology reflect the process of naming of a complex and systemic conceptual apparatus of this interdisciplinary field. Multicomponent linguistic units demonstrate new sides of a concept, united by both elements of similarity and difference [9: 607]

\section{CONCLUSION}

This comparative analysis of the modern film terminology from the point of view of the terms origin and derivational modeling in Bulgarian, Russian and Ukrainian languages gives an idea of the patterns of the formation and function of the field-specific terms. The formation and functional patterns of the film terminology have a similar development in these three languages, which is a consequence of the international nature of the film industry as a whole.

The obtained results allow to outline new aspects in the study of cinematography terminology in Slavic languages and have an applied orientation.

\section{References}

[1] Terminologicheskiy slovar' po kul'turologii [The terminological dictionary of cultural studies] / sost. V. L. Benin, YE. D Zhukova. - Moskva: Izdatel'stvo "Flinta", 2017. 743 p. [In Russian]

[2] Kino. Entsiklopedicheskiy slovar' [Cinema. Encyclopedic Dictionary] / Gl. red. S. I. Yutkevich. Moskva: Sovetskaya entsiklopediya, 1986. 637 p. [In Russian]

[3] V. N. Myslavskyi, Kinoslovnyk. Terminy, vyznachennia, zharhonizmy. [Film dictionary. Terms, definitions, jargon] Kharkiv, 2007. 328 p. [In Ukrainian]

[4] Yu. V. Shcherbinina, Kniga - tekst - kommunikatsiya. Slovar'spravochnik noveyshikh terminov i ponyatiy [Book - text communication. Dictionary-reference book of the latest terms and concepts]. Moskva: FORUM: INFRA-M, 2015. 304 p. [In Russian]

[5] Bol'shoy Rossiyskiy entsiklopedicheskiy slovar' [Large Russian encyclopedic dictionary]. Repr. izd. Moskva: Bol'shaya Rossiyskaya entsiklopediya, 2009. Available from: 
http://niv.ru/doc/dictionary/encyclopedic/fc/slovar-207103.htm\#zag-101909 [In Russian]

[6] Slovar'-spravochnik terminov normativno-tekhnicheskoy dokumentatsii [Dictionary-reference book of terms of normative and technical documentation]. 2015. Available from: https://normative_reference_dictionary.academic.ru/ Russian]

[7] V. A. Batig, Sopostavitel'nyy analiz naimenovaniya zhanrov kino $\mathrm{v}$ angliyskom i russkom yazykakh [Comparative analysis of the names of film genres in English and Russian]. In: Vestnik Sankt-Peterburgskogo universiteta. Ser. 9, Vyp.2, 2013, 99-103. [In Russian]

[8] L. Yu. Buyanova, Terminologicheskaya derivatsiya v yazyke nauki: kognitivnost', semiotichnost', funktsional'nost' [Terminological derivation in the language of science: cognitive, semiotic, functional]. Moskva: FLINTA: Nauka, 2014. 256 p. [In Russian]

[9] D. Surudzhiyska, Ekranna izraznost pri otrazyavane na bedstviya. [Screen expression in disaster coverage]. In: Retorika i komunikatsii, № 7, 2013. Available from: http://rhetoric.bg/\%D1\%80\%D0\%B5\%D1\%82\%D0\%BE\%D1 $\% 80 \% \mathrm{D} 0 \% \mathrm{~B} 8 \% \mathrm{D} 0 \% \mathrm{BA} \% \mathrm{D} 0 \% \mathrm{~B} 0-\% \mathrm{D} 0 \% \mathrm{~B} 8$

$\% \mathrm{D} 0 \% \mathrm{BA} \% \mathrm{D} 0 \% \mathrm{BE} \% \mathrm{D} 0 \% \mathrm{BC} \% \mathrm{D} 1 \% 83 \% \mathrm{D} 0 \% \mathrm{BD} \% \mathrm{D} 0 \% \mathrm{~B} 8 \%$ D0\%BA\%D0\%B0\%D1\%86\%D0\%B8\%D0\%B8$\% \mathrm{D} 0 \% \mathrm{~B} 1 \% \mathrm{D} 1 \% 80 \% \mathrm{D} 0 \% \mathrm{BE} \% \mathrm{D} 0 \% \mathrm{~B} 9-7-$

$\% \mathrm{D} 1 \% 8 \mathrm{~F} \% \mathrm{D} 0 \% \mathrm{BD} \% \mathrm{D} 1 \% 83$ [In Bulgarian]

[10] L. Raycheva, Tvorcheskiyat protses v televiziyata. [The creative process in television] Sofiya: Universitetsko izdatelstvo ,Sv. Kliment Ohridski", 1996. [In Bulgarian]

[11] R. S. Stoyanova, Architectural Terms in Russian as an Art Form in Relation to Their Origin and Word-Formative Modeling: Preliminary Observations. Proceedings of the 6th International Conference on Education, Language, Art and Inter-cultural Communication (ICELAIC 2019), 24-25 October 2019, Moscow (Ser. Advances in Social Science, Education and Humanities Research [ASSEHR]; Vol. 378), 378, Paris et. al.: Atlantis Press, 2019, 601-608.

[12] M. Popova, Teoriya na terminologiyata [Theory of terminology]. Veliko Tarnovo: IK ,Znak 94", 2012. 687 p. [In Bulgarian] 